\title{
PENGGUNAAN MEMBRAN KERAMIK UNTUK MENURUNKAN BAKTERI E. COLI DAN TOTAL SUSPENDED SOLID (TSS) PADA AIR PERMUKAAN
}

\author{
Kasam, Eko Siswoyo, Rina Ayu Agustina \\ Jurusan Teknik Lingkungan \\ Fakultas Teknik Sipil dan Perencanaan, Universitas Islam Indonesia \\ JL. Kaliurang Km 14,4 Yogyakarta Telp (0274) 896440 \\ Email : kasam@ftsp.uii.ac.id
}

\begin{abstract}
Abstrak
Air permukaan biasanya mengandung berbagai parameter pencemar yang merugikan jika air tersebut akan digunakan sebagai air minum. Adapun parameter yang cukup tinggi pada air permukaan adalah bakteri E. Coli dan Total Suspended Solid (TSS). Salah satu alternative pengolahan untuk parameter bakteri E. Coli dan TSS adalah dengan filtrasi dengan membran filter. Membran keramik adalah salah satu alat yang bisa digunakan sebagai filter pada air permukaan. Penelitian ini bertujuan untuk mengetahui kinerja membran keramik dalam menurunkan E.Coli dan TSS pada air permukan. Metode penelitian dilakukan dengan menggunakan membran keramik ukuran diameter $10 \mathrm{~cm}$ dan tinggi $20 \mathrm{~cm}$ yang terbuat dari tanah lempung, pasir kwarsa dan serbuk gergaji dengan komposisi 7,5\% (membran 1) dan 10\% (membran 2) bertujuan untuk membuat porositas dan pembakaran pada temperatur 900 - 1200 oC. Selanjutnya air permukaan dialirkan pada membran keramik secara kontinyu. Pengujian E.Coli dan TSS dilakukan pada menit ke 30, 60, 90, 120, 150, dan 180 dari waktu pengaliran. Dari hasil pengujian E. Coli dan TSS, diketahui bahwa membran keramik dapat menurunkan parameter E.Coli dan TSS pada air permukaan. E. Coli menurun hingga 98\% untuk kedua membran 7,5\% dan $10 \%$ serbuk gergaji. Sedangkan TSS menurun hingga 72,55\% pada membran keramik $7,5 \%$ dan $65,22 \%$ pada membran $10 \%$.
\end{abstract}

Kata kunci : $\quad$ Air permukan, Membran keramik, E.Coli, TSS.

\section{Pendahuluan}

Teknologi membran mulai digunakan sebagai alat penjernihan air pada tahun 1960 an melalui perkembangan dengan membran sintetik perrformansi tinggi. Penerapan membran untuk pengolahan air dengan menggunakan material baru dan berbagai konfigurasi. Selanjutnya penggunaan membran digunakan untuk pengolahan air laut pada tahun 1970. Dengan keberhasilan penggunaan membran untuk pengolahan air bersih mapun air laut, maka teknologi membran terus berlajut sebagai alternative pengolahan dan diterima oleh pasar. Seiring dengan peraturan tentang air bersih yang lebih banyak dan ketat, maka teknolgi membran bisa sebagai pilihan teknolgi yang memungkinkan mempunyai efektifitas dan efisiensi yang tinggi (Amjad. Z at all, 1993). Terdapat berbagai tipe 
membran dalam proses pengolahan air yaitu mikrofiltrasi (MF), ultrafiltrasi (UF), reverse osmosis (RO), dan nanofiltrasi (NF). Membran MF mempunyai ukuran pori paling besar sehingga hanya mampu menahan partikel besar dan jenis mikroorganisme tertentu. Membran UF mempunyai yang lebih kecil dari MF oleh karena itu disamping menahan partikel besar dan mikroorganisme, UF juga mampu menahan bakteri dan makromolekul. Sedangkan pori UF dan RO lebih kecil dari NF sehingga mampu menahan ion-ion garam dan zat organik. (Perry, R. H at all, 1997). Material membran kebanyakan dibuat dari polimer organik sintetik, seperti membran MF dan UF dibuat dari material yang sama namun kondisi formasinya berbeda sehingga ukuran pori menjadi berbeda. Selain material organik, membran juga bisa dibuat dari material inorganic seperti keramik dan logam. Keramik membran biasanya stabil terhadap panas, tahan secara kimia, dan sering digunakan sebagai membran mikrofiltrasi (Baker, R. W. at all, 2004).

Berbagai aplikasi membran keramik dalam pengolahan air, seperti: keramik membran UF dan NF yang digunakan sebagai pengolahan air hasil dari produksi minyak mentah (crude oil) dan gas alam, dimana banyak mengandung zat organic dan inorganic. Diperoleh bahwa membran UF dan NF efektif untuk meisahkan minyak, emulsi, lumpur, tetapi mudah dikotori oleh lilin dan aspal (K. Shams Ashaghi, at all, 2007). Filter keramik yang dibuat dari campuran tanah lempung, sekam padi, dan dibakar pada temperatur $900{ }^{\circ} \mathrm{C}$ selama 8 jam telah digunakan untuk pengolahan air skala rumah. Diketahui bahwa filter tersebut mampu menyisihkan antara 97,8 \% dan $100 \%$ bakteri (Vinka A Oyanedel-Craver, at all, 2008). Membran keramik yang digunakan sebagai pengolahan air sungai secara langsung menunjukkan bahwa turbiditas dapat terolah antara 3 sampai $100 \mathrm{FNU}$, aliran filter dari 80 - $300 \mathrm{~L} / \mathrm{m}^{2} \mathrm{~h}$ dengan hasil recovery antara 95,9 sampai 98,9\% . (A. Loi-Brügger, at all, 2006).

E.Coli adalah bakteri yang berbentuk batang gram negatif yang dapat membentuk spora. Pada umumnya tidak dapat memproduksi $\mathrm{H}_{2} \mathrm{~S}$, tetapi beberapa strain mendapatkan plasmid dari salemonella sehingga mampu memproduksi gas $\mathrm{H}_{2} \mathrm{~S}$. Sporanya mudah dirusak oleh panas, germisida dan disinfektan pada konsentrasi rendah. Punya tiga jenis antigen yaitu $O$, H, dan K. Mempunyai sejumlah fimbrae atau phili sebagai alat melekat pada host. Bakteri ini biasanya dapat menyebabkan penyakit diare. Bakteri golongan Coli ini berasal dari usus besar (faeces) dan tanah. Bakteri pathogen yang mungkin ada dalam air antara lain adalah : Bakteri typhsum, Vibrio colerae, Bakteri dysentriae, Entamoeba hystolotic., dan Bakteri enteritis (penyakit perut). Air yang mengandung golongan Coli dianggap telah 
berkontaminasi (berhubungan) dengan kotoran manusia. Dengan demikian dalam pemeriksaan bakteriologik, tidak langsung diperiksa apakah air itu telah mengandung bakteri pathogen, tetapi diperiksa dengan indikator bakteri golongan Coli (Sutrisno, 1990). Penentuan kualitas mikrobiologis sumber air dilatarbelakangi dasar pemikiran bahwa air tersebut tidak akan membahayakan kesehatan si peminum. Dan dalam konteks ini maka penentuan kualitas mikrobiologis air didasarkan terhadap analisis kehadiran jasad indicator yang selalu ditemukan dalam tinja manusia/hewan berdarah panas baik yang sehat maupun tidak. Jasad ini tinggal dalam usus manusia/hewan berdarah panas dan merupakan suatu bakteri yang dikenal dengan nama bakteri Coliform. Bila dalam sumber air ditemukan bakteri Coliform ini maka hal ini merupakan indikasi bahwa sumber tersebut telah mengalami pencemaran oleh kotoran manusia/hewan berdarah panas (Suriawiria, 1996).

Padatan tersuspensi total (Total Suspended Solid atau TSS) adalah bahan-bahan tersuspensi (diameter $>1 \mu \mathrm{m}$ ) yang tertahan pada saringan millipore dengan diameter pori $0,45 \mu \mathrm{m}$. TSS terdiri atas lumpur dan pasir halus serta jasad-jasad renik, yang terutama disebabkan oleh kikisan tanah atau erosi tanah yang terbawa ke badan air. Materi yang tersuspensi adalah materi yang mempunyai ukuran lebih besar daripada molekul/ion yang terlarut. Dalam air alam ditemui dua kelompok zat, yaitu zat terlarut seperti garam dan molekul organis, dan zat padat tersuspensi dan koloidal seperti tanah liat, kwarts. Perbedaan pokok antara kedua kelompok zat ini ditentukan melalui ukuran/diameter partikel-partikel. Perbedaan antara kedua kelompok zat yang ada dalam air alam cukup jelas dalam praktek manum kadang-kadang batasan itu tidak dapat dipastikan secara definitif. Dalam kenyataan sesuatu molekul organis polimer tetap bersifat zat yang terlarut, walaupun panjangnya lebih dari $10 \mu \mathrm{m}$, sedangkan beberapa jenis zat padat koloid mempunyai sifat dapat bereaksi seperti sifat zat-zat yang terlarut.

Total Suspended Solid (TSS) adalah jumlah berat dalam $\mathrm{mg} / \mathrm{L}$ kering lumpur yang ada didalam air buangan setelah mengalami penyaringan dengan membran berukuran 0,45 mikron (Sugiharto, 1987). Total Suspended Solid menyebabkan kekeruhan air, tidak larut, dan tidak dapat mengendap langsung. Total Suspended Solid (TSS) dapat melayang didalam air dan akan menghalangi masuknya sinar matahari kedalam lapisan air. Padahal sinar matahari Sangat dibutuhkan oleh mikroorganisme untuk melakukan fotosíntesis. Karena tidak adanya sinar matahari maka proses fotosíntesis tidak dapat berlangsung dan akibatnya kehidupan mikroorganisme jadi terganggu. 
Analisa zat padat dalam air sangat penting bagi penentuan komponen-komponen air secara lengkap, juga untuk perencanaan serta pengawasan proses-proses pengolahan dalam bidang air minum maupun dalam bidang air buangan. Zat-zat padat yang berada dalam suspensi dapat dibedakan menurut ukurannya sebagai partikel tersuspensi koloidal (partikel koloid) dan partikel tersuspensi biasa (partikel tersuspensi). Zat padat tersuspensi dapat mengendap apabila keadaan air cukup tenang ataupun mengapung apabila sangat ringan, materi inipun dapat disaring. Koloid sebaliknya sulit mengendap dan tidak dapat disaring dengan saringan (filter) air biasa. Jenis partikel koloid tersebut adalah penyebab kekeruhan dalam air (efek tyndall) yang disebabkan oleh penyimpangan sinar nyata yang menembus suspensi tersebut. Partikel-partikel koloid tidak terlihat secara visual sedangkan larutannya (tanpa partikel koloid) yang terdiri dari ion-ion dan molekul-molekul tidak pernah keruh. Larutan menjadi keruh bila terjadi pengendapan (presipitasi) yang merupakan keadaan kejenuhan dari sesuatu senyawa kimia. Partikel-partikel tersuspensi biasa mempunyai ukuran lebih besar dari partikel koloid dan dapat dikatakan keruh karena sebenarnya air diantara partikel-partikel tersuspensi tidak keruh dan sinar tidak menyimpang.

Seperti halnya ion-ion dan molekul-molekul (zat yang terlarut), zat padat koloidal dan zat padat tersuspensi dapat bersifat inorganik (tanah liat, kwarts) dan organis (protein, sisa makanan dan ganggang, bakteri). Dalam metode analisa zat padat, pengertian zat padat total adalah semua zat-zat yang tersisa sebagai residu dalam suatu bejana, bila sampel air dalam bejana tersebut dikeringkan dalam suhu tertentu.

Berdasarkan beberapa kajian tentang pemanfaatan membran dalam pengolahan air, maka pada kegiatan ini telah dilakukan penelitian tentang penggunaan membran keramik sebagai pengolahan air, khususnya untuk penurunan bakteri E. Coli dan TSS. Tujuan penelitian adalah untuk mengetahui tingkat efektifitas membran keramik dalam menurunkan E. Coli dan TSS pada air permukaan.

\section{Metode Penelitian}

\section{Persiapan Instalasi}

Membran Keramik yang digunakan dalam penelitian ini adalah terbuat dari tanah lempung, pasir kwarsa dan serbuk gergaji. Tanah lempung yang digunakan dalam pembuatan gerabah adalah tanah lempung yang berasal dari Kasongan. Ukuran keramik yaitu: tinggi $12.5 \mathrm{~cm}$ dan diameter $9 \mathrm{~cm}$. Komposisi serbuk gergaji dibuat 7,5\% terhadap 
total bahan (membran 1) dan 10\% (membran 2). Untuk bak penampung air baku (raw inlet) dan air filtrate (air olutlet) dibuat dari kaca, seperti terlihat pada gambar 1. Sedangkan proses pengaliran menggunakan bantuan pompa $A c=220-240 \mathrm{v} / \mathrm{Hz}$ dan $\mathrm{w}=15$ watt.

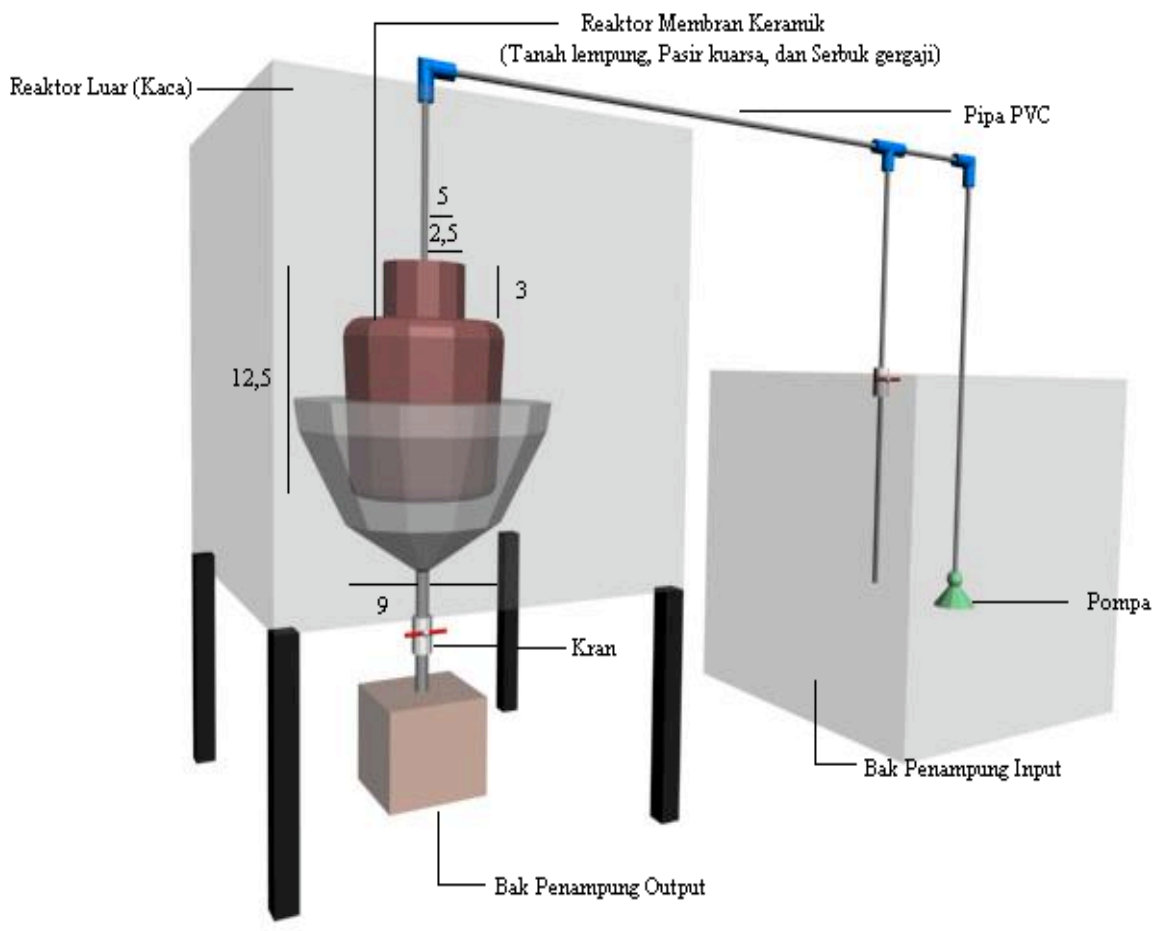

Gambar 1. Instalasi membran keramik

\section{Runing dan sampling}

Proses running dari instalasi adalah air permukaan dari tempat penampungan (inlet) mengalir melalui pipa menuju membran keramik (gerabah), dengan bantuan pompa. Air permukaan yang mengalir kedalam membran keramik tersebut akan merembes melewati pori-pori dinding keramik, yang kemudian ditampung pada bak penampung luar. Pengambilan sampel dilakukan pada waktu pengaliran 30, 60, 90, 120, 150, dan 180 menit. Sedangkan pengujian E.Coli menggunakan metode MPN 333 menurut Formula Thomas dan pengujian TSS menggunakan SK SNI M-03-1990F.

\section{Analisa Data}

Analisa data untuk penentuan tingkat kinerja dari instalasi roughing filter dalam menurunkan konsentrasi COD dan warna, yang dihitung dengan persamaan overall efficiency yaitu: 


$$
\eta=\frac{C o-C e}{C o} x 100 \%
$$

Dengan: $\quad \eta=$ Overall Eficiency $(\%)$

$$
\begin{aligned}
& \mathrm{Co}=\text { Konsentrasi Awal }(\mathrm{mg} / \mathrm{L}) \\
& \mathrm{Ce}=\operatorname{Konsentrasi} \text { Akhir }(\mathrm{mg} / \mathrm{L})
\end{aligned}
$$

Selain itu dilakukan analisa data dengan uji t-test yang bertujuan untuk melihat ada tidaknya perbedaan yang signifikan antara konsentrasi awal dengan masing-masing titik pengambilan sampel, sehingga dapat disimpulkan :

a. Jika $t_{\text {hitung }} \geq t_{\text {tabel}}$, maka tolak Ho artinya ada perbedaan yang signifikan antara hasil analisa inlet dan outlet.

b. Jika $t_{\text {hitung }} \leq t_{\text {tabel}}$, maka terima Ho artinya tidak ada perbedaan yang signifikan antara hasil analisa inlet dan outlet.

\section{Hasil dan Pembahasan}

Berdasarkan hasil pengukuran terhadap porositas membran keramik diketahui bahwa menbran 1 mempunyai ukuran pori $34,40265 \times 10^{-4} \mathrm{~mm}$ dan pori membrane 2 sebesar $33,89180 \times 10^{-4} \mathrm{~mm}$. Sedangkan hasil pengujian air inlet diketahui bahwa kandungan E.Coli adalah $1898 \mathrm{MPN} / 100 \mathrm{~mL}$ pada membran 1 dan membran 2. Sedangkan TSS $=114$ $\mathrm{mg} / \mathrm{L}$ untuk membran 1 dan $113 \mathrm{mg} / \mathrm{L}$ untuk membran 2. Selanjutnya untuk hasil pengujian air outlet (filtrate) seperti ditunjukkan pada tabel 1 dan tabel 2 berikut:

Tabel 1. Kandungan E.Coli dan Efisiensi Penurunannya

\begin{tabular}{|c|c|c|c|c|c|}
\hline $\begin{array}{c}\text { Sampling } \\
\text { (menit ke) }\end{array}$ & $\begin{array}{c}\text { Inlet } \\
\text { (MPN/100 } \\
\text { ml) }\end{array}$ & \multicolumn{2}{|c|}{ Membran1 1 } & \multicolumn{2}{c|}{ Membran 2 } \\
\hline & & $\begin{array}{c}\text { Outlet } \\
\text { (MPN/100ml) }\end{array}$ & $\begin{array}{c}\text { Efisiensi } \\
(\%)\end{array}$ & $\begin{array}{c}\text { Outlet } \\
\text { (MPN/100ml) }\end{array}$ & $\begin{array}{c}\text { Efisiensi } \\
(\%)\end{array}$ \\
\hline 30 & 1898 & 438 & 77 & 438 & 77 \\
\hline 60 & 1898 & 139 & 93 & 139 & 93 \\
\hline 90 & 1898 & 438 & 77 & 1898 & 0 \\
\hline 120 & 1898 & 271 & 86 & 44 & 98 \\
\hline 150 & 1898 & 86 & 95 & 116 & 94 \\
\hline 180 & 1898 & 44 & 98 & 139 & 93 \\
\hline
\end{tabular}


Tabel 2. Konsentrasi TSS dan Efisiensi Penurunannya

\begin{tabular}{|c|c|c|c|c|c|c|}
\hline \multirow{2}{*}{$\begin{array}{c}\text { Sampling } \\
\text { (menit ke) }\end{array}$} & \multicolumn{3}{|c|}{ Membran1 1 } & \multicolumn{3}{c|}{ Membran 2 } \\
\cline { 2 - 7 } & $\begin{array}{c}\text { Inlet } \\
(\mathbf{m g} / \mathbf{L})\end{array}$ & $\begin{array}{c}\text { Outlet } \\
(\mathbf{m g} / \mathbf{L})\end{array}$ & $\begin{array}{c}\text { Efisiensi } \\
(\mathbf{\%})\end{array}$ & $\begin{array}{c}\text { Inlet } \\
(\mathbf{m g} / \mathbf{L})\end{array}$ & $\begin{array}{c}\text { Outlet } \\
(\mathbf{m g} / \mathbf{L})\end{array}$ & $\begin{array}{c}\text { Efisiensi } \\
(\%)\end{array}$ \\
\hline 30 & 114 & 68 & 40.35 & 113 & 60 & 46.43 \\
\hline 60 & 106 & 60 & 43.4 & 102 & 52 & 49.02 \\
\hline 90 & 100 & 52 & 48 & 106 & 48 & 54.72 \\
\hline 120 & 96 & 48 & 50 & 100 & 36 & 64 \\
\hline 150 & 94 & 40 & 57.45 & 98 & 36 & 63.27 \\
\hline 180 & 102 & 28 & 72.55 & 92 & 32 & 65.22 \\
\hline
\end{tabular}

Sebelum dilakukan pengujian E.Coli dilakukan pencucian terlebih dahulu pada keramik tersebut dan running dengan menggunakan air bersih. Proses pencucian dan running ini bertujuan untuk menghilangkan kotoran-kotoran sisa dari hasil pembakaran keramik/gerabah agar tidak bercampur dengan hasil akhir/effluent pada membran keramik tersebut. Pada penelitian ini air baku yang digunakan yaitu air permukaan Selokan Mataram. Hasil dari pengolahan air baku dengan menggunakan membran keramik diambil pada inffluent dan effluent dari membran keramik yang dilakukan per 30 menit selama 3 jam $(30,60,90,120,150$, dan 180 menit). Jika air baku telah terlihat merembes (berupa butiran-butiran sepeti keringat) keluar dari membran keramik maka perhitungan awal untuk pengambilan sampel dimulai kemudian air hasil pengolahan dengan membran keramik diambil dan disimpan dalam botol kemudian diuji konsentrasi E.Coli di laboratorium. Pengambilan inlet dilakukan setiap pengambilan outlet dikarenakan disetiap menitnya konsentrasi E.Coli berubah-ubah (tidak stabil).

Penurunan konsentrasi E.Coli dengan menggunakan membran keramik juga terjadi karena adanya proses penyaringan (filtrasi) dan penyerapan (adsobsi), dimana bahan-bahan organik yang terdapat pada air buangan disaring dan diserap oleh membran keramik dengan tekanan yang kuat menyebabkan bahan-bahan organik menempel pada dinding membran, sehingga air yang keluar lebih bersih. Hal itu terjadi karena E.Coli yang berukuran 0.5 - 1 mikron dapat tersaring oleh membran keramik yang berpori lebih kecil daripada E.Coli. Dan variasi waktu sangat berpengaruh untuk mengetahui waktu jenuh sampel air.

Proses filtrasi pada membran keramik berfungsi untuk menyaring dan menangkap bahanbahan padat, bahan-bahan terlarut, dan bahan-bahan tersuspensi yang terdapat pada air baku atau air buangan. Selain proses filtrasi yang terjadi pada membran keramik, terjadi 
juga proses adsorpsi yang terjadi akibat tumbukan antara partikel-partikel tersuspensi dengan serbuk gergaji, yang merupakan campuran dalam pembuatan membran keramik, yang merupakan hasil daya tarik menarik partikel-partikel yang bermuatan listrik berlawanan. Serbuk gergaji yang terdapat dalam membran keramik tersebut mempunyai muatan listrik negatif, dengan demikian mampu mengadsorbsi partikel-partikel positif.

Bilamana adsorban dibiarkan berkontak dengan suatu larutan, jumlah zat terlarut yang diadsorbsi pada permukaan adsorban akan meninggkat sehingga konsentrasi zat terlarut akan menurun setelah beberapa saat. Kesetimbangan adsorpsi akan tercapai bilamana jumlah molekul yang meninggalkan permukaan adsorban sama dengan jumlah molekul yang diadsorpsi pada permukaan adsorban. Sifat-sifat reaksi adsorpsi yang dapat dilihat dengan mengaitkan kapasitas adsorpsi (massa zat terlarut yang dapat diadsorpsi persatuan massa adsorban) pada konsentrasi kesetimbangan zat terlarut yang tertinggal dalam larutan karena adsorpsi merupakan fenomena fisik yang menyangkut permukaan suatu material maka adsorban yang baik harus berupa struktur berpori yang memiliki permukaan cukup luas setara dengan volumenya, dimana dalam hal ini membran keramik berfungsi sebagai adsorban sedangkan air selokan mataram berfungsi sebagi adsorbat/ solute.

Perlakuan yang sama juga dilakukan pada pengujian parameter Total Suspended Solid (TSS) sebelum melakukan pengujian di laboratorium yaitu melakukan pencucian dan running pada membran keramik dengan menggunakan air bersih. Dari tabel 2 ditunjukkan bahwa pada instalasi membran keramik dengan komposisi $7,5 \%$ dan $10 \%$ menunjukkan terjadinya penurunan konsentrasi TSS pada inlet, hal ini disebabakan karena terjadinya proses pengendapan partikel-partikel yang terdapat dalam air baku. Hal ini dapat terjadi karena kondisi air baku yang sangat tenang (laminer), sehingga partikel-partikel yang memiliki berat yang lebih besar mudah untuk mengendap.

Penurunan konsentrasi TSS pada outlet dapat terjadi karena membran keramik memiliki kemampuan untuk menyaring (filtrasi) dan menyerap (adsorpsi) padatan tersuspensi (TSS) yang terdapat pada air baku. Membran keramik sebagai penyaring (filter), karena pada membran keramik terdapat campuran serbuk gergaji berukuran 50 mess yang berfungsi untuk merembeskan air. Sedangkan fungsi membran keramik sebagai penyerap (adsorbsi) dapat terjadi karena pada membran keramik terdapat mineral lempung yang dapat dengan mudah menyerap beberapa molekul organik yang terdapat di dalam air baku. Hal ini terlihat dari ukuran pori membran keramik yang jauh lebih kecil dibandingkan ukuran 
padatan tersuspensi yaitu dengan diameter $>1$ mikron, sehingga membran keramik efektif dalam menurunkan konsentrasi TSS.

Dari analisa analisa t-test dengan menggunakan uji t pada data hasil pengujian E. Coli dan TSS menunjukkan bahwa seluruh nilai t lebih besar dari t tabel maka dapat dikatakan bahwa adanya perbedaan penurunan yang signifikan antara inlet dan outlet pada E. Coli dan TSS.

\section{Kesimpulan}

Dari serangkaian running, pengujian dan analisis terhadap air permukaan Selokan Mataram dengan menggunakan membran keramik diperoleh kesimpulan sebagai berikut:

1. Membran keramik dengan komposisi serbuk gergaji $7,5 \%$ dan $10 \%$ mampu menurunkan E.Coli yang signifikan yaitu sampai dengan $98 \%$.

2. Penurunan TSS $72,55 \%$ pada membran keramik $7,5 \%$ dan $65,22 \%$ pada membran keramik $10 \%$.

3. Waktu yang efektif dalam menurunkan konsentrasi E.Coli dan TSS pada air permukaan Selokan Mataram pada menit ke 180.

\section{Daftar Pustaka}

1. (Amjad, Z., Ed, 1993, Reverse Osmosis: Membran Technology, Water Chemistry, and Industrial Applications; Van Nostrand Reinhold: New York).

2. A. Loi-Brügger, S. Panglisch, P. Buchta, K. Hattori, H. Yonekawa, Y. Tomita, R. Gimbel, 2006, Ceramic membrans for direct river water treatment applying coagulation and microfiltration, Water Science \& Technology: Water Supply Vol 6 No 4).

3. Baker, R. W., 2004, Membran Technology and Applications, $2^{\text {nd }}$ ed.; John Wiley \& Sons, Ltd.: Chichester).

4. K. Shams Ashaghi, M. Ebrahimi, P. Czermak., 2007, Ceramic Ultra- and Nanofiltration Membrans for Oilfield Produced, Water Treatment: A Mini Review, The Open Environmental Journal, 2007, Bentham Science Publishers Ltd).

5. Sugiharto, 1987, Dasar-dasar Pengelolaan Air Limbah. Penerbit Universitas Indonesia, Jakarta.

6. Perry, R. H.; Green, D. W., Eds, 1997, Perry's Chemical Engineers' Handbook, 7th ed.; cGraw-Hill: New York).

7. Vinka A Oyanedel-Craver, James A Smith, 2008, Sustainable Colloidal-SilverImpregnated Ceramic Filter for Point-of-Use Water Treatment, Environmental Science \& Technology. Easton: Feb 1, 2008. Vol. 42). 